\title{
Teachers' Reported Use of Marzano's Instructional Strategies in United Arab Emirates K-12 Schools
}

\author{
Abdurrahman Ghaleb Almekhlafi \\ United Arab Emirates University, Al-Ain, Abu Dhabi, United Arab Emirates, \\ almekhlafi@uaeu.ac.ae
}

Sadiq Abdulwahed Ismail

Assoc. Prof., Hamdan Bin Rashid Al Maktoum Foundation for Distinguished Academic Performance, United Arab Emirates, ism232@gmail.com

Abdelmoniem Ahmed Hassan

Alazahar University, Egypt,ah21348@gmail.com

\begin{abstract}
Successful teaching depends on many factors, including the application of effective instructional strategies. However, teacher perception of instructional strategy application in the classroom is of paramount importance. Empirical research conducted by Marzano and others showed that there are instructional strategies that improve teaching outcomes. Based on his pedagogical research, Marzano suggested nine instructional strategies that teachers could use for effective teaching. The present study investigated teachers' reported use and implementations of those instructional strategies in their own classes. The study participants included 512 teachers from K-12 schools in the United Arab Emirates. The differences between participants concerning their reported utilization of Marzano's strategies were also investigated. The results of the study showed that teachers in the United Arab Emirates (UAE) are very much aware of and familiar with Marzano's instructional strategies. Other results also demonstrate that UAE schools' teachers have already been practicing Marzano's instructional learning strategies in addition to the contextual common practice strategies that they have been trained to use and have adapted in their own classes. However, differences between teachers' reported use were not prevalent. Recommendations are provided and the implications of the study's findings are discussed.
\end{abstract}

Keywords: Marzano's instructional strategies, teachers' report, learning, instruction, Marzano, K-12 schools

Citation: Almekhlafi, A. G., Ismail, S. A., \& Hassan, A. A. (2020). Teachers' Reported Use of Marzano's Instructional Strategies in United Arab Emirates K-12 Schools. International Journal of Instruction, 13(1), 325-340. https://doi.org/10.29333/iji.2020.13122a 


\section{INTRODUCTION}

Educators worldwide, including in the United Arab Emirates (UAE), want to ensure that all students are being prepared for $21^{\text {st }}$ century university life. To achieve this, teachers must use effective instructional strategies in their classrooms. Researchers define instructional strategies (e.g., Marzano, 2003; Wiggins \& McTighe, 2008) as the classroom techniques and methods teachers use to introduce learning contents to their students and help them acquire required knowledge and skills. Researchers worldwide have studied different teaching strategies and methods in different contexts including learning and enhancing language skills. Teachers' perceptions were also investigated in many of these studies (e.g., Bernel, 2012; Miller, 2014; Jeanmarie-Gardner, 2013; Alsheikh, 2014, 2018; AlHusban \& Alkhawaldeh, 2017; Endley, 2016; \& Dubas \& Toledo, 2016).

Marzano, either alone or with colleagues, has conducted numerous studies on these instructional strategies and their application in teaching. Examples of these studies include Marzano, 2012, 2010, 2009, 2007, 2003; Marzano, \& Pickering, 2007; Marzano, Marzano, \& Pickering, 2003; Marzano, Pickering, \& Pollock; 2001; Marzano, Gaddy, \& Dean 2000; \& Haystead, \& Marzano, 2009). However, there is a dearth of such studies about Marzano's instructional strategies within the context of the present study. As a result, the present research paper represents the initial stage in exploring how those strategies are viewed and the level of their implementations by different teachers. Consequently, there is an urgent need for a study like this one since the UAE is very eager to try and endorse any innovative initiations and/or ideas that might contribute to enhance students' learning outcomes in particular and the whole education system in country in general.

Marzano (2003) indicated that instructional strategies affect student learning, especially when these strategies are organized, well planned, systematically applied in the classroom, and properly evaluated (Akdeniz, 2016, p. 62). Mayer (2008) pointed out that teaching is a complicated process that requires the teacher to use effective instructional strategies that promote students' learning and guide their cognitive processes. However, the use of any teaching strategy is affected by a teacher's perception of its effectiveness in achieving the desired learning outcomes (Nola \& Irzik, 2005). This perception provides rich information that can be used to assess teaching effectiveness. Similarly, according to Wozney et al. (2006), if a teacher's perception of a strategy is positive, then its use will be more frequent than otherwise. This was confirmed by Schunk (2003), who found that a favorable perception of a teaching strategy results in higher motivation to use it in the classroom.

Marzano's nine instructional strategies, which were based on research findings on effective teaching strategies (Marzano, 2003), serve as the framework of the present study. Teacher perceptions and application of these nine strategies have been extensively researched in the United States (Dean et al., 2012; DuFour \& Marzano, 2011; Kwon, 2015; Marzano, 2003; Marzano, 2007; Marzano \& Pickering, 2010; Marzano et al., 2001; Marzano et al., 2005; Rohrer \& Pashler, 2010). However, no previous research has been conducted in the UAE to explore teachers' perceptions of 
and reported use of Marzano's nine instructional strategies. Furthermore, the results of the present study might extend the use of Marzano's strategies to other educational contexts. According to Marzano et al. (2005), teachers' perceptions of the teaching and learning process is essential, and thus schools must consider this.

\section{LITERATURE REVIEW}

Recently, there has been growing interest in the effects of different instructional strategies on learning outcomes, including the nine instructional strategies developed by Marzano et al. (2001). This interest is rooted in the belief that instructional strategies play a significant role in the academic success or learning achievements of students of all ages (Hirsch, 2000). Several studies have demonstrated that instructional strategies may affect learning outcomes (Dean et al., 2012; DuFour \& Marzano, 2011; Ford, 2018; Kwon, 2015; Marzano, 2003; Marzano, 2007; Marzano et al., 2001; Marzano et al., 2005; Marzano \& Pickering, 2010; Rohrer \& Pashler, 2010).

Kwon (2015) used a survey questionnaire to conduct a comparative analysis of Korean elementary and middle school instructors' views of instructional strategies. Marzano's strategies were used to compare the views of elementary and middle schoolteachers. The results revealed no significant differences between the views of these groups. However, the analysis revealed that the teachers' views of the importance of these instructional strategies were higher than their actual use of the strategies in the classroom.

Although instructional strategies are good tools to enhance learning, no single instructional strategy may serve in all learning situations with all learners. The instructional strategy's effectiveness depends on the context in which it is used. Marzano et al. (2001) paid special attention to successful instruction to identify beneficial strategies that play significant roles in improving learning outcomes. The objective of their study was to identify the most effective instructional strategies contributing to the success and accomplishment of all learners. Ensuring that learners meet the target learning outcomes depends on effective instructors who can choose and implement the right instructional strategies to ensure learning success in their classroom context.

Nevertheless, the use of appropriate instructional strategies alone may not ensure learners meet the target goals unless instructors possess knowledge of their students' learning needs and know how and when to implement the appropriate strategies within their classroom contexts (Cherasaro et al., 2015; Marzano, 2009; Marzano \& Toth, 2014).

Thomas and Green (2015) examined the frequency and differences in strategy use in two different schools. Their results revealed that teachers need to choose their instructional strategies based on the learning situation, needs, and abilities of each student. In addition to assessing the needs of their students, teachers should also provide learners with direction and support (Northouse, 2010; Rowe, 2007).

Pressley and Harris (2008) emphasized the importance of both procedural and declarative knowledge for the enhancement of metacognitive strategies. To nurture the 
use of metacognitive strategies, it is essential to provide learners with abundant opportunities to practice and utilize them at different times and in different contexts (Scharlach, 2008). These strategies may include summarizing, predicting, visualizing, guessing, etc. To ensure the effectiveness of these strategies, students must be provided with many opportunities to assess and evaluate the effects on their learning. Thus, it is very important to conduct any form of assessment using both convergent questions (controlled answers) and divergent questions (open-ended questions). Haidar and $\mathrm{Al}$ Naqabi (2008) stressed the need for using different questions that require the learners to use metacognitive strategies.

Rohrer and Pashler (2010) discussed the idea of both effective learning strategies and strategies capable of enhancing durable learning. The researchers reviewed three different focuses of research relevant to learning outcomes enhancement. Research has shown that testing the "temporal dynamic" (spreading study over a longer period) and the "interleaving of different types of practice problems" may play essential roles in promoting effective learning. They concluded that if educational practices can be adjusted to reflect the results of research, both educational and learning outcomes would be improved.

\section{Theoretical Framework}

Marzano suggested nine research-based instructional strategies for improving student learning (Marzano, 2003; Marzano, 2007; Marzano et al., 2001). The first strategy is setting objectives and providing feedback, which had an average effect size of .61 and percentile gain of 23 in student achievement (Marzano et al., 2001, p. 7). The second strategy is reinforcing effort and providing recognition. Marzano et al. (2001) found that this strategy had an effect size of .80 and a percentile gain of 29 . The third strategy deals with cooperative learning that enhances student achievement across all subjects and age groups, for tasks involving higher order thinking skills (Hatti, 2009; Johnson \& Johnson, 2008); this strategy had an effect size of .73 and a 27-percentile gain in student achievement. The fourth strategy concerns homework and practice. Cooper et al. (2006) investigated this strategy and found that homework groups outperformed no homework groups by a 28-percentile gain in achievement, with an effect size of .77. As for the fifth strategy that deals with questions, cues, and advance organizers, Marzano et al. (2001) found an average effect size of .59 , with a 22-percentile gain in student achievement. The sixth strategy emphasizes summarizing, note taking, and requires students to restate the main ideas of a text passage in their own words (Fiorella \& Mayer, 2015; Marzano, 2007). These two strategies related to student achievement had an effect size of 1 and a 34-percentile gain (Marzano et al., 2001, p. 7). The seventh strategy involves identifying similarities and differences. Marzano (2007) identified four tasks that facilitate the application of this strategy: comparing, classifying, and creating metaphors and analogies. All these tasks had an effect size of 1.61 and 45-percentile gain in (Marzano et al., 2001, p. 7). The eighth strategy involves creating and testing hypotheses. Marzano (2007, pp. 90-97) identified four types of hypothesis-generation and testing tasks: experimental inquiry, problem solving, decision-making, and investigation. These tasks had an average effect size of .61 and a 23-percentile gain in (Marzano et al., 2001, p. 7). 
The ninth strategy is based on nonlinguistic representations, and assists students in converting linguistics materials into images using activities such as creating graphics and presentations; making physical models; generating mental pictures; and drawing pictures, pictographs, Venn diagrams, and concept maps (Marzano, 2007, p. 37). In terms of student achievement, this strategy had a 27-percentile gain and an effect size of .75 (Marzano et al., p. 7).

Marzano's strategies form an essential part of pedagogical content knowledge. This knowledge is affected by teachers' years of experience and level of teaching expertise.

\section{Statement of the Problem}

Teaching requires skills, knowledge, patience, and energy. Success or failure in the teaching profession depends very much on knowledge, experience, and ability to choose and implement appropriate and effective strategies in the classroom. Although Marzano's strategies are studied and implemented globally, in the educational context of the UAE, there is a dearth of research on these strategies. Based on the researchers' knowledge and experience in K-12 schools in the UAE, it is clear that teachers are rarely applying Marzano's strategies. Furthermore, informal discussions with teachers and administration conducted by the researchers indicated that many teachers are not aware of good teaching practices. Thus, this study aims to spread knowledge of effective teaching strategies to teachers in the UAE.

The purpose of this study was to examine UAE teachers' reported use of Marzano's nine instructional strategies. Furthermore, it investigated teachers' application of Marzano's instructional strategies in their classrooms.

\section{Research Question}

The present study examined the following research question: What are UAE teachers' reported use of Marzano's instructional strategies in their classrooms?

\section{METHOD}

\section{Research Design}

The present study used a survey research design to investigate UAE teachers' reported use of Marzano's instructional strategies.

\section{Participants}

The participants consisted of a random sample of 512 teachers from different K-12 schools in the UAE. These teachers represented all seven Emirates: Abu Dhabi, Dubai, Al-Sharjah, Al-Fujairah, Ajman, Ras Al-Khaimah, and Um Al-Quwain. The participants' range of teaching experience was from one year to more than 30 years of teaching experience. Male teachers comprised $23 \%$ of all participants, while female teachers comprised $77 \%$. These teachers had various qualifications: About $10 \%$ had diplomas, 76 had BAs, 3\% had MAs, and 1\% had PhDs, while 10\% the rest did not report their qualifications. The participants taught various subjects, namely, math, 
science, English, Arabic and Islamic studies, social studies, PE, music, and art (see Table 1).

Table 1

Percentages of Participating Teachers According to Subject Taught

\begin{tabular}{ll}
\hline Subject & Percentage \\
\hline Arabic/Islamic studies & 32.6 \\
English & 20.1 \\
Science & 13.7 \\
Math & 10.3 \\
Social studies & 10.1 \\
PE & 1.2 \\
Music & .2 \\
Art & .8 \\
Other & 11.1 \\
\hline
\end{tabular}

\section{Data Collection}

\section{Questionnaire}

A 50-item questionnaire on Marzano's instructional strategies was designed for the study and included the following subscales:

1. Setting objectives and providing feedback

2. Reinforcing effort and providing recognition

3. Cooperative learning

4. Homework and practices

5. Questions, cues, and advance organizers

6. Summarizing and note-taking

7. Identifying similarities and differences

8. Creating and testing hypotheses

9. Identifying similarities and differences

To test the validity of the questionnaire, it was first distributed to a panel of university professors who reviewed it and provided feedback that was used to improve its contents and structure. The questionnaire was distributed by the researchers and assistant researchers to $640 \mathrm{~K}-12$ teachers across the UAE. The teachers were given a one-week deadline to complete the questionnaire and return it as a hard copy. All teachers were informed that their participation in the study was not mandatory, and that they could withdraw at any time if they decided not to participate. The total number of returned, completed questionnaires was 512 , an $80 \%$ response rate, which is considered an acceptable rate within the paradigm of survey research. 


\section{Data Analysis}

SPSS 24.0 was used for data analysis.

\section{Validity and Reliability}

\section{Instrument construct validity}

To establish the construct validity of Marzano's Instructional Strategies Scale, the researchers conducted a Principal Component Analysis (PCA) by applying the KaiserMeyer-Olkin Measure of Sampling Adequacy (KMO) and Bartlett's test of sphericity to confirm the results of the PCA (see Table 2). The KMO value indicated that the sample was adequate, $\mathrm{KMO}=0.945$. In addition, all $\mathrm{KMO}$ values for individual items were greater than 0.6, which is the acceptable limit (Field, 2009, p. 647).

Table 2

KMO and Bartlett's Test Results

\begin{tabular}{lll}
\hline KMO & & .945 \\
\hline Bartlett's test of sphericity & Approx. Chi-Square & 13455.02 \\
& Df & 1255 \\
& Sig. & .000 \\
\hline
\end{tabular}

Bartlett's test of sphericity, which tests the overall significance of all correlations within the correlation matrix, was highly significant $\left(\chi^{2}=5670.14, p \leq 0.001\right)$, indicating that the factor analysis was appropriate (Field, 2009, p. 648).

An initial factor analysis of the 50 items yielded nine factors using the eigenvaluesgreater-than-one rule; this combination explained $62.91 \%$ of the variance. A varimax rotation was also performed. The rotated matrix is displayed in Table 3. Only items with factor loadings above .30 are displayed. Eight factors were retained after performing the varimax rotation. Factor 9 was eliminated because it had only two items, one of which was loaded high under Factor 7. Thus, the remaining item did not constitute a factor. Factor 1 represents the questions, cues, and advance organizer strategy. Factor 2 represents the creating and testing hypotheses strategy. Factor 3 represents the summarizing and note-taking strategy. Factor 4 represents the homework and practices strategy. Factor 5 represents the identifying similarities and differences strategy. Factor 6 represents the reinforcing effort and providing recognition strategy. Factor 7 represents the cooperative learning strategy. Finally, Factor 8 represents the setting objectives and providing feedback strategy.

\section{Reliability}

The researchers conducted an internal consistency reliability test using Cronbach's alpha for each factor (subscale). Factors $1,2,3,4,5$, and 6 had high reliability $(\alpha=0.92,0.93$, $0.90,0.85,0.79,0.74$ respectively), while Factors 7 and 8 had moderate reliability ( $\alpha=$ 0.67 and 0.65 respectively). See Table 3 for a summary of the results. 
Table 3

Summary of Factor Analysis Results for the Instructional Strategies Scale

\begin{tabular}{llllll}
\hline Factor & $\begin{array}{l}\text { \# of } \\
\text { Items }\end{array}$ & Eigenvalue & $\begin{array}{l}\text { of } \\
\text { Variance }\end{array}$ & $\begin{array}{l}\text { Cronbach' } \\
\text { s } \alpha\end{array}$ \\
\hline 1. Questions, cues, and advance organizers & 9 & 17.05 & 34.1 & .92 \\
2. Creating and testing hypotheses & 6 & 4.32 & 8.46 & .93 \\
3. Summarizing and note-taking & 7 & 1.89 & 3.79 & .90 \\
4. Homework and practice & 8 & 1.77 & 3.54 &. .85 \\
5. Identifying similarities and differences & 7 & 1.44 & 2.88 & .79 \\
6. Reinforcing efforts and providing & 4 & 1.39 & 2.77 & .74 \\
recognition & & & & \\
7. Cooperative learning & 4 & 1.32 & 2.63 & .67 \\
8. Setting objectives and providing feedback & 4 & 1.19 & 2.73 & .65 \\
\hline
\end{tabular}

\section{FINDINGS}

To answer the research question, "What are UAE teachers' reported use of Marzano's instructional strategies in their classrooms?" the researchers used descriptive statistics such as means, standard deviations, and percentages. Table 4 displays the descriptive statistics of the eight factors. As can be seen from the table, the main scores for the factors $1,2,3$, and 7 were a little bit lower than the mean score for factors 4, 5, 6, and 8 . However, in all cases the mean scores were moderate for the first set of factors ranging from 3.46 to 3.69 on a 5-pint Likert scale, whereas the mean scores were high for the second set of factors ranging from 4.30 to 4.47 on the same 5-point Likert scale. However, all those results, regardless of their high or low levels, demonstrate that teachers in the UAE are aware and familiar with Marzano's instructional strategies and they are existing in their instructional practices in one way or another.

Table 4

Means and Standard Deviations of Teachers' Reported use of Marzano's Instructional Strategies

\begin{tabular}{lllllllll}
\hline & Factor 1 & Factor 2 & Factor 3 & Factor 4 & Factor 5 & Factor 6 & Factor 7 & Factor 8 \\
\hline $\mathrm{N}$ Valid & 504 & 504 & 505 & 507 & 507 & 507 & 509 & 509 \\
$\quad$ Missing & 5 & 5 & 4 & 2 & 2 & 2 & 0 & 0 \\
Mean & 3.69 & 3.68 & 3.60 & 4.30 & 4.31 & 4.43 & 3.46 & 4.47 \\
Median & 3.77 & 3.83 & 3.71 & 4.37 & 4.42 & 4.50 & 3.50 & 4.50 \\
Std. Deviation & .82 & .92 & .86 & .53 & .48 & .47 & .73 & .50 \\
\hline
\end{tabular}

On the other hand, Table 5 shows the percentages of the respondents' reported use of Marzano's instructional strategies in their classrooms. As can be seen from the table, the same set of factors $1,2,3$, and 7 are lower in the frequency of reported use in the higher end of the scale (often, and always) than the second set of factor 4, 5, 6, and 8. The percentages of the reported use for factors $1,2,3$, and 7 are 44.2, 42.4, 40.2, and 30.6 respectively. On the other hand, the percentages for factors $4,5,6$, and 8 are 79.5, 80.5, 87.0, and 87.2 respectively. Thus, findings indicate that participants reported using "Homework and practice", "Identifying similarities and differences", "Reinforcing effort and providing recognition", and "Setting objectives and providing feedback" more often and/or 
always than using "Questions, cues, and advance organizers", "Generating and testing hypotheses", "Summarizing and note-taking", and "Cooperative learning". The above-mentioned results highlight the fact that teachers have already been using those strategies, but without abandoning completely the regular teaching/learning strategies that they have been familiar with and have implemented in their own classes.

Table 5

Percentages of Teachers' Reported use of Marzano's Instructional Strategies

\begin{tabular}{|c|c|c|c|c|c|}
\hline Marzano Strategy & Never & Rarely & Sometimes & Often & Always \\
\hline $\begin{array}{l}\text { Questions, cues, and advance organizers } \\
\text { (F1) }\end{array}$ & 3.2 & 13.3 & 39.3 & 40.6 & 3.6 \\
\hline Generating and testing hypotheses (F2) & 4.8 & 11.7 & 36.5 & 33.7 & 8.7 \\
\hline Summarizing and note-taking (F3) & 4.4 & 16.00 & 39.4 & 37.6 & 2.6 \\
\hline Homework and practice $(\mathrm{F} 4)$ & 00 & 2.4 & 18.1 & 71.2 & 8.3 \\
\hline $\begin{array}{l}\text { Identifying similarities and differences } \\
\text { (F5) }\end{array}$ & 00 & 1.4 & 18.1 & 73.6 & 6.9 \\
\hline $\begin{array}{l}\text { Reinforcing effort and providing } \\
\text { recognition }(\mathrm{F} 6)\end{array}$ & 00 & .4 & 12.6 & 67.1 & 19.9 \\
\hline Cooperative learning (F7) & 1.2 & 20.9 & 47 & 27.7 & 2.9 \\
\hline $\begin{array}{l}\text { Setting objectives and providing feedback } \\
\text { (F8) }\end{array}$ & 00 & .8 & 12.00 & 63.2 & 24 \\
\hline
\end{tabular}

\section{DISCUSSION AND RECOMMENDATIONS}

The purpose of the present study was to examine UAE teachers' reported use of Marzano's instructional strategies in the classroom. The research data were analyzed using descriptive statistics, namely the mean, standard deviation, and percentages of the composite scores of the teachers' responses to the survey questions concerning Marzano's instructional strategies. In general, all teachers' scores fell above the mean (see Table 4). However, the teachers' applications differed from one strategy to another. Table 5 shows that the teachers rated four of the instructional strategies as often or always above $78 \%$. These strategies were setting objectives and providing feedback $(87.2 \%)$, reinforcing effort and providing recognition $(87 \%)$, identifying similarities and differences $(80.5 \%)$, and homework and practice $(78.5 \%)$.

Table 5 shows that $87 \%$ of the teachers reported that they set lesson objectives and provide students with the necessary feedback. The findings of several previous studies support this result (Marzano \& Brown 2009; Wise \& Okey, 1983). These studies indicated that student achievement was higher in classrooms that employed the "setting objectives" strategy compared to classrooms that did not. Moreover, as shown in Table 4 , the participants of the present study reported using feedback with their students, but it is not clear from the results whether the teachers used feedback after formative or summative assessment or both. Marzano et al. (2019) indicated that the most frequently used type of feedback was formative, and as the amount of formative assessment and feedback increases, student learning also increases (p. 13).

Concerning reinforcing effort and providing recognition, the findings of the present study are consistent with several others (Hattie et al., 1996; Kumar, 1991 as cited in Marzano et al., 2001; Stipek \& Weisz, 1981). As Table 5 shows, 87\% of the teachers 
claimed that they used this strategy in their classrooms. However, the findings of this study are inconsistent with those of Cameron and Pierce (1994) and Deci et al. (2001) concerning providing students with recognition in terms of praise or rewards. A plausible reason for this discrepancy is that the results of our study depend on selfreported data while the other studies were based on meta-analyses with low average effect sizes or negative effect sizes (Marzano, 2007).

When the participants were asked about applying the strategy of identifying similarities and differences, almost $81 \%$ responded that they often or always applied it in their classrooms. Cognitive research supports these findings (e.g., Bransford et al., 1999). Employing these strategies helps to raise student achievement from 31 to 46 percentile points (Baker \& Lawson, 1995; Gick \& Holyoak, 1980; Halpren et al., 1990). It seems that the teachers in our sample were aware of this and implemented similarities and differences sub-strategies, such as comparing, classifying, and generating analogies.

As for the strategy of homework and practice, $79 \%$ of teachers reported that they used it in their classrooms. This finding is consistent with Cooper et al. (2006) and Marzano (2007), who found a positive relationship between homework and student achievement. The results in this study may be attributed to (a) the amount of time specified by teachers for students to complete homework, (b) making the purpose of homework clear to students, and (c) the homework completion rate.

Table 5 also demonstrates that four strategies were rated as often or always less than $50 \%$ of the time. These four strategies include questions, cues, and advance organizers $(44.2 \%)$, generating and testing hypotheses (42.4\%), summarizing and note taking (40.2\%), and cooperative learning (30.6\%).

Forty-four percent of those who were surveyed indicated that they applied questions, cues, and advance organizers strategies often or always. However, 39\% reported using these strategies sometimes. These results are consistent with the findings of Dong (2009), Wright and Bilica (2007), Mitchell (2006), Marzano et al. (2001), and Spires and Donley (1998). All these research studies pinpoint the importance of activating students' prior knowledge by employing questions, cues, and advance organizers.

Table 5 shows that almost $42 \%$ of the participants reported (often or always) using the generating and testing hypotheses in their classroom, whereas $37 \%$ reported using it sometimes. Almost sixteen percent of the teachers reported using this strategy rarely or never in their classrooms. From these results, it is evident that a large proportion of the UAE teachers employed this strategy in their teaching. The present findings are consistent with Oh (2012), Marzano (2007), Park (2006), Marzano et al. (2001), and Lawson et al. (2000).

Although forty percent of the participants reported that they usually or always used the summarizing and note-taking strategy, $39 \%$ of the participants reported only using them occasionally. These results are inconsistent with Garner (1984) (as cited in Littlefield, 2011), who found that even experienced teachers did not provide much explicit instruction in summarizing for elementary school students. However, other studies support our results (Fiorella \& Mayer, 2015; Littlefield, 2011; Marzano, 2001). 
Almost all teachers reported using the cooperative learning strategy in their classrooms. Surprisingly, $31 \%$ percent of the participants in the present study (either usually or always) reported using cooperative learning in their classroom, whereas $47 \%$ of the participants reported that they sometimes used this strategy. These results are inconsistent with those of Antil et al. (1998), who found that $93 \%$ of teachers used cooperative learning regularly, while $81 \%$ used it daily.

\section{LIMITATIONS}

The present study has several limitations, which may to some extent impact the generalizability of its results. First, the study covers only public schools. Thus, the generalization of its results might not extend to teachers in private schools. Another limitation is that this study focused on quantitative data collection, which does not provide very comprehensive or detailed results.

\section{CONCLUSION}

This study's results may have different implications for different school levels and grades, as well as different school subjects. The results of the present study may also have implications at other levels beyond classroom practices, such as at the levels of decision-making, curriculum planning, in-service and pre-service teacher training and preparation, etc. Researchers hope that this study will contribute to understanding of the importance of Marzano's nine instructional strategies and the role they play in improving instructional practices and student learning. By understanding how teachers perceive and implement these strategies, curriculum developers and teacher trainers will be able improve professional development and training for those who require it.

The results revealed that the teachers were aware of the importance of Marzano's strategies. Their perceptions were positively high toward the use of the different categories of these strategies. Similarly, their reported use of these strategies in their classes was high as well. This clearly indicates that many teachers in the UAE are familiar with Marzano's instructional strategies and they have integrated them in their own classes. It might be concluded that the practice of those strategies is partially in place in some schools and grade levels. Thus, it is very important to generalize the use of those instructional strategies at all schools and/or grade levels and provide teachers with all the necessary support and training.

Based on the study results, the researchers recommend the following:

1. Provide the field with appropriate support and hands-on training that could help in spreading the practice of these strategies on a large scale, including in private schools and other educational institutions.

2. Conduct further research investigating Marzano's instructional strategies from different angles such as focusing on teachers' actual instructional practices concerning the implementation of Marzano's nine strategies in their classes. This will definitely make a substantial contribution to the field since there is a scarcity of studies on this topic in the UAE context. 
Pilot Marzano's instructional strategies at different grade levels in a number of schools in each emirate and provide a concrete and thorough assessment report about their effectiveness in improving students' learning outcomes.

\section{REFERENCES}

Akdeniz, C. (Ed.). (2016.) Instructional process and concepts in theory and practice: Improving the teaching process. Singapore: Springer.

AlHusban, N. A. \& Alkhawaldeh, A. (2017). Exploring English as a foreign language (EFL) female teachers' knowledge of Marzano's research-based instructional strategies $\&$ its relationship with their level of performance in teaching reading comprehension at the educational directorate of Zarqa. Dirasat, Educational Sciences, 43(5), 2195-2207.

Alsheikh, N. (2018). The primacy of bilinguals and trilingual college students' views on reading and language learning, English Language Teaching, 11(1), 150-163.

Alsheikh, N. (2014). The perceived and actual use of metacognitive reading strategies by the UAE high school students, Journal of ELT and Applied Linguistics (JELTAL), 2(1), 140-153.

Antil, L. R., Jenkins, J. R., Wayne, S., \& Vadasy, P. E. (1998). Cooperative learning: Prevalence, conceptualization, and the relation between research and practice. American Educational Research Journal, 35(3), 419-454. doi: https://doi.org/10.3102/00028312035003419.

Baker, W. P., \& Lawson, A. E. (1995). Effect of analogical instruction and reasoning level on achievement in general genetics. Tempe: Department of Zoology, Arizona State University.

Bernel, R.T. (2012). A study of the effectiveness of selected instructional strategies from the Marzano causal teacher evaluation model in a third-grade classroom at an online charter school (Unpublished doctoral dissertation). University of Akron, Ohio, US.

Bransford, S. D., Brown, A. L., \& Cocking, R. R. (Eds.). (1999). How people learn: Brain, mind, experience and school. Washington, DC: National Academy Press.

Cameron, J., \& Pierce, W. (1994). Reinforcement, reward, and intrinsic motivation: A meta-analysis. Review of Educational Research, 64(3), 463-423.

Cherasaro, T. L., Reale, M. L., Haystead, M., \& Marzano, R. J. (2015). Instructional improvement cycle: A teacher's toolkit for collecting and analyzing data on instructional Strategies (REL 2015-080). Washington, DC: U.S. Department of Education, Institute of Education Sciences, National Center for Education Evaluation and Regional Assistance, Regional Educational Laboratory Central. Retrieved from http://ies.ed.gov/ncee/edlabs.

Cooper, H., Robinson, J. C., \& Patall, E. A. (2006). Does homework improve academic achievement? A synthesis of research, 1987-2003. Review of Educational Research, 76(1), 1-62. 
Dean, C. B., Hubbell, E. R., Pitler, H., \& Stone, B. (2012). Classroom instruction that works: Research-based strategies for increasing student achievement. Alexandria, VA: The Association for Supervision and Curriculum Development.

Deci, E. L., Koestner, R., \& Ryan, R. M. (2001). Intrinsic reward and intrinsic motivation in education: Reconsidered one again. Review of Educational Research, 71(10), 1-27.

Dong, Y. R. (2009). Linking to prior learning. Educational Leadership, 66(7), 26-31.

Dubas, J. M. \& Toledo, S. A. (2016). Taking higher order thinking seriously: Using Marzano's taxonomy in the economics classroom. International Review of Economics Education, 21, 12-20.

DuFour, R., \& Marzano, R. J. (2011). Leaders of learning: How district, school, and classroom leaders improve student achievement. Bloomington, IN: Solution Tree Press.

Endley, M. J. (2016). Proficiency as a variable in Gulf EFL students' employment of reading strategies. Reading in a Foreign Language, 28(2), 183-233.

Field, A. (2009). Discovering statistics using SPSS. London: Sage.

Fiorella, L., \& Mayer, R. E. (2015). Learning as a generative activity: Eight learning strategies that promote understanding. New York: Cambridge University Press.

Ford, C. (2018). Effective practice instructional strategies: Design of an instrument to assess teachers' perception of implementation. Studies in Educational Evaluation, 56, 154-163. doi: 10.1016/j.stueduc.2017.12.004.

Gick, M. L., \& Holyoak, K. J. (1980). Analogical problem solving. Cognitive Psychology, 12, 306-353.

Haidar, A. H., \& Al Naqabi, A. K. (2008). Emirati high school students' understandings of stoichiometry and the influence of metacognition on their understanding. Research in Science \& Technological Education, 26(2), 215-237.

Halpern, D. F., Hansen, C., \& Reifer, D. (1990). Analogies as an aid to understanding and memory. Journal of Educational Psychology, 82(2), 298-305.

Hattie, J. (2009). Visible learning: A synthesis of meta-analyses relating to achievement. New York, NY: Routledge.

Hattie, J., Biggs, J., \& Purdie, N. (1996). Effect of learning skills intervention on student achievement: A meta-analysis. Review of Educational Research, 66, 99-136.

Halpern, D. F., Hanson, C., \& Riefer, D. (1990). Analogies as an aid to understanding and memory. Journal of Educational Psychology, 82(2), 298-305.

Haystead, M. W., \& Marzano, R. (2009). Meta-analytic synthesis of studies conducted at Marzano research laboratory on instructional strategies. Englewood, CO: Marzano Research Laboratory. 
Hirsch, E. (2000). Reality's revenge: Research and ideology. In L. Abbeduto (Ed.) Taking sides: Clashing views on controversial issues in educational psychology (pp. 158-175). Guilford, CT: Duskin-McGraw Hill.

Jeanmarie-Gardner, C. (2013). Utilizing Marzano's summarizing \& note taking strategies on seventh grade students' mathematics performance (Unpublished doctoral dissertation). St. John's University, New York, US.

Johnson, D. W., \& Johnson, R. T. (2008). Cooperation and the use of technology. In J. M. Spector, M. D. Merrill, J. V. Merrienboer, \& M. P. Driscoll (Eds.). Handbook of research on educational, communication, and technologies (pp. 402-423). New York: Lawrence Erlbaum Associates.

Kwon, H. (2015). Teachers' perceptions on instructional strategies. Advanced Science and Technology Letters, 115, 18-22. doi: 10.14257/astl.2015.115.04

Lawson, A. E., Clark, B., Meldrum, E. C., Falconer, K. A., Soquist, J., \& Kwon, Y. (2002). Development of scientific reasoning in college biology: Do two levels of general hypotheses testing skills exist? Journal of Research in Science Teaching, 37(1), 81-101.

Littlefield, A. R. (2011). The relationship among summarizing instruction, support for student choice, reading engagement, and expository text comprehension (Unpublished doctoral dissertation). The Catholic University of America, Washington, US.

Marzano, R. J. (2012). A study of best practices in Edmentum online solutions. An analysis and interpretation of a Marzano research laboratory study. Bloomington, MN

Marzano, R. J. (2010). The art and science of teaching/representing knowledge nonlinguistically. The Key to Changing the Teaching Profession, 67(8), 84-88.

Marzano, R. J., \& Pickering, D. J. (2007). Special topic: The case for and against homework. Educational leadership, 64(6), 74-79.

Marzano, R. J., Marzano, J. S., \& Pickering, D. (2003). classroom management that works: Research-based strategies for every teacher. ASCD.

Marzano, R. J., Gaddy, B. B., \& Dean, C. (2000). What works in classroom instruction? Mid-continent Research for Education and Learning.

Marzano, R. J. (2003). What works in schools: Translating research into action? Alexandria, VA: Association for Supervision and Curriculum Development.

Marzano, R. J. (2007). The art and science of teaching: A comprehensive framework for effective instruction. Alexandria, VA: The Association for Supervision and Curriculum Development.

Marzano, R. J. (2009). Setting the record straight on "high-yield" strategies. Phi Delta Kappan, 91(1), 30-37.

Marzano, R. J., \& Brown, J. L. (2009). A handbook of the art and science of teaching. Alexandria, VA: Association for Supervision and Curriculum Development. 
Marzano, R. J., \& Pickering, D. J. (2010). The highly engaged classroom: The classroom strategies series (Generating high levels of student attention and engagement). Marzano Research Laboratory.

Marzano, R. J., Pickering, D. J., \& Heflebower, M. (2011). The highly engaged classroom. Bloomington, Indiana: Marzano Research Laboratory.

Marzano, R. J, Pickering, D. J., \& Pollock, J. E. (2001). Classroom instruction that works: Research-based strategies for increasing student achievement. Alexandria, VA: Association for Supervision and Curriculum Development.

Marzano, R. J., \& Toth, M. D. (2014). Teaching for rigor: A call for a critical instructional shift. Learning Sciences: Marzano Center. Retrieved from https://www.learningsciences.com/wp/wp-content/uploads/2018/05/Teaching-for-RigorA-Call-for-a-Critical-Instructional-Shift.pdf

Marzano, R., Waters, T., \& McNully, B. (2005). School leadership that works: From research to results. Alexandria, VA: The Association for Supervision and Curriculum Development.

Mayer, R. E. (2008). Learning and instruction. Upper Saddle River, NJ: Pearson.

Miller, S. (2014). In-service teacher training \& coaching on Marzano's instructional strategies: An action research study (Unpublished doctoral dissertation). Capella University, Minnesota, US.

Mitchell, K. E. (2006). Getting to the heart of a story. Teaching Pre-K-8, 37(1), 66-67.

Nola, R., \& Irzik, G. (2005). Philosophy, science, education, and culture. Heidelberg, Netherlands: Springer.

Northouse, P. G. (2010). Situational approach. In L. Shaw, S. Quesenberry, \& A. Hope (Eds.), Leadership theory and practice (pp. 89-109). Thousand Oaks, CA: Sage.

Oh, P. S. (2012). How can teachers help students formulate scientific hypotheses? Some strategies found in abductive inquiry activities of earth science. International Journal of Science Education, 32(4), 541-560.

Park, J. (2006). Modeling analysis of students' processes of generating scientific explanatory hypotheses. International Journal of Science Education, 82(5), 569-489.

Pressley, M., \& Harris, K. R. (2008). Cognitive strategies instruction: From basic research to classroom instruction. The Journal of Education, 189(1/2), 77-94.

Rohrer, D., \& Pashler, H. (2010). Recent research on human learning challenges conventional instructional strategies. Educational Researcher, 39(5), 406-412.

Rowe, G. W. (2007). The situational approach to leadership. In P. Beamish (Ed.), Cases in leadership (pp. 125-155). Thousand Oaks, CA: Sage.

Scharlach, T. (2008). START comprehending: Students and teachers actively reading text. Reading Teacher, 62(1), 20-31. 
Schunk, D. (2003). Self-efficacy for reading and writing: Influence of modeling, goalsetting and self-evaluation. Reading and Writing Quarterly, 19, 159-172.

Spires, H. A., \& Donley, J. (1998). Prior knowledge activation: Inducing engagement with informational texts. Journal of Educational Psychology, 90(2), 249-260. doi: 10.1037/0022-0663.90.2.249.

Thomas, I. A., \& Green, R. L. (2015). Using instructional strategies to enhance student achievement. National Forum of Teacher Education Journal, 25(3), 1-18.

Wozney, L., Vivek, V., \& Abrami, P. (2006). Implementing computer technologies: Teachers' perceptions and practices. Journal of Technology and Teacher Education, 14 (1), 173-208.

Wiggins, G., \& McTighe, J. (2008). Put understanding first. Educational Leadership, 65(8), 36-41.

Wise, K. C., \& Okey, J. R. (1983). A meta-analysis of effects of various scienceteaching strategies on achievement. Journal of Research in Science Teaching, 20(2), 419-435.

Wright, S. B., \& Bilica, K. (2007). Instructional tools to probe biology students' prior understanding. American Biology Teacher, 69(1), 1-5. 